\title{
Singing my way to Social Justice
}

\author{
Karan Casey ${ }^{1 *}$ \\ 1 University of Limerick, Ireland \\ *karancasey@hotmail.com
}

Received: 30 March 2017 ; Accepted: 29 September 2017 ; Published: 1 November 2017

Editor: Michael Viega Reviewer: Daphne Rickson

\begin{abstract}
My name is Karan Casey and I am a singer. In this paper I am interrogating the performance of social justice, and how my ideals are performed, as an Irish woman, as a social activist, as a traditional and a folk singer, and as a cultural voice. Having a 25-year career as an Irish singer I will be emphasising the voice of the professional artist and how my power as an active agent and participant in this setting gets to the heart of social responsibilities that are important to me. I will be investigating my song choices to see if they contribute to a discussion of social justice and how this is demonstrated performatively and through the text. You can approach this article in two ways. You can click here on the link for the full performance or you can scroll down through this paper and play the songs within the context of my writing. I hope you enjoy it, whichever pathway you choose.
\end{abstract}

Keywords: Irish traditional song, protest song, folk music, social justice,

\section{Introduction}

\section{"Singing My Way to Social Justice."}

My name is Karan Casey and I am a singer. I have been a professional singer performing worldwide in Ireland, Europe, Japan, and America. I have made 10 albums to date and have collaborated and guested on over 50 albums. Primarily I am an Irish folk singer who is greatly informed by the Irish song tradition. In this paper I am interrogating the performance of social justice. Having a 25-year career as an Irish singer I will be emphasising the voice of the professional artist and how my power as an active agent and participant in this setting gets to the heart of social responsibilities that are important to me. My life has been deeply enriched by singing and my songs shape and mirror my ambitions for the world that we live in. My view of social justice is a shared world for all humanity, where women are treated equally, poverty is eradicated, and there is an end to violence that is so often fuelled by greed. In essence, many of the songs I sing are songs of social justice with the aim of furthering and promoting love and compassion.

The purpose of this paper is to investigate my song choices to see if

1: They contribute to a discussion of social justice;

2: How this is demonstrated performatively and through the text.

You can approach this article in two ways. You can click here on the link for the full performance or you can scroll down through this paper and play the songs within the context of my writing. I hope you enjoy it whichever pathway you choose. 


\section{Cultural Background of the Performance}

As an Irish female folk singer I stand proudly in the time-honoured Irish tradition of singing out against oppression. Many of the songs are from the point of view of a voiceless and vulnerable people and reflect our woes as an oppressed people. Ireland was colonised by the English from the $12^{\text {th }}$ century onwards. Within our song tradition, the real narrative of our country continues to be written. It is our gift to the world. Songs such as Shamrock Shore, The Wind that Shakes the Barley, Revenge for Skibbereen, Sailing off to Yankee Land, and the Croppy Boy, are just a few examples. Frank Harte ${ }^{1}$, the legendary folk singer and song collector stated that "Those in power write the history while those who suffer write the songs. And we have an awful lot of songs" (Harte, 1998). I had the great privilege of collecting songs and stories from Frank Harte from 1995 to 2005. I went on to record and perform these gifts, songs such as Shamrock Shore, The Wind that Shakes the Barley, Johnny I hardly Knew Ya, One I Love, Roger the Miller, Dunlavin Green, The Brown and Yellow Ale The Song of Choic,e and The King's Shilling being but a small section of the songs he gave me.

Mostly I would describe myself as a folk singer, greatly informed by the tradition, and I think this audio-visual is evidence of a 'folky gig.' The term 'folk' is complex when applied to song. But as an initial attempt at a definition, and not to be too prescriptive, a folk singer in Ireland often has an eclectic approach, taking songs from many related genres, with known as well as unknown composers. Breandán Breathnach in his book Folk Music and Dances of Ireland (1971) describes folk music as music that "Includes not only the older songs and melodies of the Gael, which are undoubtedly our most precious heritage, but also the Anglo-Irish and English ballads of the countryside and the extraordinary rich vein of dance music which belongs exclusively neither to Gaeltacht or Galltacht.” (Breathnach, 1971, p. 2) 'Folk' is really a broader or umbrella term for music in Ireland. As a folk singer greatly informed and influenced by traditional song, I would state that a traditional singer in Ireland is mostly defined as someone who is a carrier of songs that have been passed onto him or her orally often within a familial framework. As Tomás Ó Canainn describes in his seminal work Traditional Music of Ireland, "the adjective traditional implies that the music is being passed from one generation of performers to the next" (O Canainn, 1978, p. 1).

\section{A Different Kind of Love Song}

Since the 1960s there has also been the advent of the folk singer in America and Europe, and this term is used to describe a person who has a strong political message and indeed is the carrier of the "songs of the people." There are numerous examples including Bob Dylan, Joan Baez, Pete Seeger, Judy Collins, Nina Simone, Dick Gaughan, Christy Moore, Andy Irvine, Mick Moloney, Mary Black, Frances Black, and Maura O'Connell. They represent alert and political voices arising from the political turmoil of the 1960s. 'Folk' is a term that is prevalent in America and stems from ideas of social activism, particularly influenced by the civil rights movement. "Activists reinvented traditional music as a political force by interpreting it as a depository of the "people or the "folk", and as providing an alternative to manufactured, mass-mediated forms of cultural expression" (Eyerman \& Barretta, 1996, p. 501). I was greatly influenced by these brave artists, and I really set out to emulate their politics and singing by becoming a folk singer.

\section{Background to the Performance}

Moving now to discuss the concert itself, prior to this, the songs had been worked up and rehearsed. The main themes that emerge in the songs I have chosen to discuss here are colonialism and war and their oppressive forces often witnessed from the woman's point of view.

My singing is motivated by a deep love of song and is an expression of my understanding of the world. The performative elements that I bring to my singing give 
meaning and a life-force to the song texts I choose. In each performance new ideas are created, musically, gesturally, and emotionally, relating and connecting or finding meaning with the audience and creating a social bond that holds cultural and political understanding within that community at the time of the performance and possibly afterwards. For myself, I prefer to evoke feelings and illuminate ideas with specific song texts and use an aesthetic approach that tries to be persuasive, rather than forceful.

In essence, the gig is formed by the set list which I choose. In deciding what songs to sing, primarily they must appeal to me on a musical level. I don't solely choose the songs because they reflect my politics. Also in trying to connect with the audience, a balance needs to be met in terms of my responsibility towards the audience and their 'night out' and in terms of my commitment to social justice. If I connect with the audience successfully as a performer, then my chances of persuading them politically are heightened.

This paper consists of an hour long video recording of a performance in the Glasgow City Halls at the Celtic Connections music festival on the $2^{\text {nd }}$ of February 2017, as well as auto-ethnographic writing to support and help clarify the ideas performed in the concert. The musicians were Niall Vallely, Donald Shaw, Karen Matheson, Seán Óg Graham, Niamh Dunne, Pauline Scanlon, Dirk Powell, Michael McGoldrick, James Macintosh, Ewen Vernal and myself. The sound was produced and recorded by Cammie Young and the video was made by Peter McNulty. I am deeply grateful to all the performers and crew who gave their permission to use this audio-visual recording.

In reflecting on my auto-ethnographic writing on my own role in the creation of this video, I find that I share Bartleet's viewpoint "that my work has nothing to do with the black notes on the page: it has to do with people and the amazing relationships that music allows us make" (Bartleet, 2009, p. 724). I owe a lot to the musicians for helping me to realise my musical vision for these particular songs.

\section{Artist-as-Researcher}

Having undertaken a Ph.D in Arts Practice in the University of Limerick, I now find myself occupying the role of researcher as well as practitioner. In my new role as artistas-researcher, I am using auto-ethnographical writings to reflect on my performances. I am mindful of my own stance while navigating the boundaries between my work as a researcher, performer, and as a social justice activist. In many ways as in life itself these areas overlap, and so the boundaries can become blurred. I will try to keep a check on this throughout this article. I state though from the outset that really this is an auto-ethnography of performance as social justice. I have been spurred on by other readings that promote the use of the personal narratives as research to support my enquiries:

personal narratives propose to understand a self or some aspect of self of a life as it intersects with cultural context, connect to other participants as co-researchers, and invite readers to enter the author's world and to use what they learn there to reflect on. (Ellis, Adams, \& Bochner, 2010, p. 46)

Hence I am inviting you, the reader and the viewer, into my head and my heart to use what I have learned in performance, so as you can reflect on the social issues that I embrace. For this article, I am going to take four songs from the performance and discuss in detail how they performatively and textually contribute to a discussion on social justice in parts one and two. The songs are The King's Shilling, Man of God, Ballad Of Accounting, and Hollis Brown.

\section{Part 1: Song Discussion}

Song 1: The King's Shilling is a Scottish anti-war anthem sung from the woman's point of view written by Iain Sinclair. For lyrics see: http://karancasey.com/Winds lyrics.html\#kingsshilling 
This song invites people to rethink our attitudes towards war. It tells of the plight of a poor soldier and how he had to go to war for money or the 'King's Shilling;' the implication being he was bribed. It also demonstrates greatly his 'jubilation' at the beginning of the third verse:

'The pipes did play as he marched along

And the soldiers sang out a battle song'

Then it relates how this poor woman was left behind in poverty struggling to bring up the 'bairnes twa' (two children) after his death. So it speaks of the futility of war and how it fails us all, time and time again. I sing it to protest ongoing colonial wars today, in Syria, Palestine, and Yemen.

Here initially, performatively, and verbally, I used humour to ingratiate myself with the audience. I think that humour in a gig helps everyone to relax, and it brings us closer as a community. Then I went on to invite the audience to sing the chorus in our shared sense of humanity. I don't think I did a great job in talking around the issue of colonialism in this performance, and I want to discuss this song and this aspect of the performance in detail. I felt as if I could have done better. Sometimes I don't steady myself enough during the gig to do a good job. But on the other hand it was a live performance. Or maybe I am too hard on myself? In any case I have decided to include it here though in an effort to show how performance is in itself a lesson and how I learn greatly through my performances.

For me, a sense of social responsibility towards the truth of the world as I see it today has always been integral and inherent to my performances. In many ways I carry on the legacy of many Irish folk singers who have always used songs as a political motivator and provocateur. My performances are subjective and I am not claiming to be objective, but they also can be viewed politically and culturally from a wide angle lens. As Chang sees "...culture as a product of interactions between self and others in a community of practice... self is the starting point for cultural acquisition and transmission" (Chang, 2008, p. 23).

I have been trying to carve out a space for myself where I can cultivate my own style of 'speaking out' or being an activist. I think this aspect of my performance needs more consideration and would benefit from more research and thinking on the subject. Further on in this article you will see how this process evolved and how I eventually came to write a new song. The 'rough take' of which is presented later.

Song 2: Man of God (Eliza Gilkyson). For lyrics see http://elizagilkyson.com/?album $=$ paradise-hotel

As evidenced in the performance video my song choices are varied. I don't mind where the song comes from as long as I can identify with it emotionally and as long as I believe it to be a good song. This song is from America and was written by Eliza Gilkyson, but it is distilled through my own Irish accent and folk sensibilities. My aesthetic sensibilities are thus difficult to pin down and my practice delivers a broad eclectic approach. This eclectic approach and belief system reaffirms and confirms my core cultural conviction and experiential wisdom that the songs are pathways to our shared sense of humanity. They bring us to one another. They carry us back and forth to new and old worlds. They are our varied, beautiful, cultural gifts to one another.

Here I ask, does my singing actually contribute to making a difference in the world? I would hope that by singing provocative political songs such as Man of God by Eliza Gilkyson that I am engaging with the audience in a deeply emotional and evocative manner. I am asking the listener to reflect on fundamentalist viewpoints of religion and how I believe they do not serve humanity well and indeed contradict the basic tenets behind most religions. I am hoping to illuminate these points through singing.

The text, is a particular call to Christian fundamentalists who consistently defend their warring by claiming that God is on their side. The first verse is a send up of George Bush, but I think it is relevant for today and reflects greatly the 'cowboys' that are in the White House in particular at present. I also really love the strong, provocative, anti-war theme, which stands fundamentalism on its head. 
Song 3: Ballad of Accounting (Ewan McColl). For lyrics see http://www.dickgaughan.co.uk/songs/texts/account.html

A song in the performance that addresses the social issue of class is, Ballad of Accounting, Ewan McColl's searing protest song asking us the people to recognise how we ourselves construct society, not the governments or rulers of the day. Perhaps the listener could engage in their own heuristic reflections? I have always growled the lines :

'Did you stand aside and let them choose while you took second best?

Did you let them skim the cream off and then give to you the rest?'

\section{If only you would just sing and not talk}

Performatively, I draw or attune the audience's attention to a specific element within the performance or to a specific line within the song. Over time I have learned that if I growl or bark or rage my way through the whole song, then people can almost feel 'assaulted' by the song and not moved. I listened myself for years to the singing of Dick Gaughan and found that he often annunciates or 'growls' some of the lines but not all of them. Growling is stressing the words and as a vocal effect, brings a guttural annunciation to particular lines. This goes back to and mirrors my initial point of choosing my moments within the evening to talk about social justice issues. I don't feel that a whole evening of my 'preaching' would work and that it sometimes alienates members of the audience. In fact, I know this from my deep experiential history of singing out social justice songs. Looking back on my memories and journaling them, I remember how one man said to me at a gig "you are such a pretty girl if only you would just sing and not talk." Another told me "to go home and sort out the problems between the Protestants and Catholics in Ireland before coming over here and telling us (Americans) how to live our lives." This comment came during the Iraq war when I was singing anti-war songs.

Song 4: Ballad of Hollis Brown (Bob Dylan). For lyric see https://bobdylan.com/ songs/ballad-hollis-brown/

Another song in the set that speaks to social justice is the Bob Dylan song Hollis Brown. It speaks to the despair and 'stolen' dignity that come with poverty. This is an incredibly evocative and provocative song. In this introduction, you can see that I got a good response from the audience. I was clearer and more confident in my delivery. The use of humour comes into play here, and Donald Shaw's comment and humour about the 'eight men' was funny. I use humour myself and like humour on stage. Humour does have a role to play in communicating with the audience. The danger is that sometimes the humour may dilute the importance or impact of my statement. Again, this is another vital part of my performance that I reflect on especially in terms of delivering thoughts on social justice. As you can see in the performance and my body language, I am really enjoying singing this song. I love it. There is something about the immediacy of new material in a performance that brings a new and energetic enthusiasm, and this is a really great song that delivers in so many areas. It borrows greatly from our own tradition in Ireland as evidenced by the long narrative, which is something I cherish. In Ireland we really only get going by around the $3^{\text {rd }}$ or $4^{\text {th }}$ verse! The scene needs to be set, and Dylan really does inhabit this poor man's mind and details and illuminates with great artistry the reality of poverty.

'Your baby's eyes look crazy they're a-tugging at your sleeve $\mathrm{x} 2$

You walk the floor and wonder why

With every breath you breathe'

I have no problem inhabiting this voice. I detest poverty and think it should not exist in the world today anywhere. There is so much money and wealth available to the 'chosen few.'

"The world's 10 richest billionaires, according to Forbes, own $\$ 505$ billion in combined wealth, a sum greater than the total goods and services most nations produce on an annual basis" (inequality.org, n.d.). 
Sometimes in the past I felt as if I didn't have the right to be singing about poverty as I wasn't poor myself, but now I stand over these songs with authority and sing away. We can all fight for a better world. Just because I have money does not mean that I turn my back on the poor and ignore poverty. The most vulnerable and how they are treated are an indictment of our society.

Of course, there are the imaginative forces that come into play here. I want to and can inhabit or imagine through the song the life of another person and thus perform and sing out their woes or joys. This is the great beauty and power of art, being able to transport ourselves to another person's way of life through a novel or a poem or a song or a photo. Along the pathway of the song my imagination is accessed, through the words of a song the doors of my imagination are opened up and I can act out or find myself living in his world. From this perspective my empathy for the man in this case can be achieved. My experience of his reality can promote and evoke compassion and carry me to another world of understanding and hopefully do the same with the audience if the performance is heartfelt and true.

\title{
Part 2: Performance of Social Justice
}

\section{Colonialism/ War}

My own stance on war is that I don't believe we should be fighting each other at all. As an Irish woman, I have witnessed how colonialism has failed us as a people and as a nation. We have struggled for so long to overcome this. But I do believe that as a nation we do need to walk out of our victimhood and walk tall as adults to forgive all that has been done to us. Ireland has such a long history of defiance that to many, it might seem like second nature, and I have been spurred on myself by the countless Irish people who have stood up to oppression. So for me, the first thing that needs to be done is to inform ourselves of the truth of the past and the present, as I do through the songs and to then take action. Make a difference, march, protest, sing, sing to your children. We all can make a difference in the world.

It is my personal intention and hope that as a listener, you will be spurred on to take action or to act on your empathy for your fellow human beings, actively go out there and march or protest against the war machine and greed, or at the very least to think about it. I posted this piece up on Facebook to advertise a benefit that I was doing in America on my March tour of 2017. It was a benefit run by Irish musicians in America who raised money for the ACLU, and we were protesting Donald Trump's disgraceful treatment of immigrants. People I have known for years and who were never politically active came and supported this gig. We raised $\$ 35,000$. It is also an example of how I build on my performative knowledge of social issues. I was moved enough on the social justice issue to take action, but also on reflecting on my own performance in the January gig in Glasgow, I felt I needed to do something more and to speak out more coherently on the issues. My activity as a researcher is paying off as demonstrated in this Facebook post where I document my ideas.

\section{Call to Action}

\author{
Facebook post (March 2):
}

Hi Folks I am in Long Island City in a hotel room musing looking over at the Queensborough Bridge. I am supposed to be working! This Friday I will be singing in Carnegie Hall in N.Y. with Lúnasa. I have fought so long and hard to get here. I can't wait! I think it is sold out. I will be singing the song 'The Kings Shilling.' I wanted to write this post though because I wanted to say exactly what singing this song means to me. Sometimes when I get out on stage I get waylaid, with fear, pressure or just the way the gig goes, you can't contain a performance. Anyway I have long been trying to make a difference in the world and I wanted to honour this in our time of great social upheaval with a considered and more practical approach to my performances. This is what I hope to say. Also this is an attempt to get people out on Sunday next the 5th of March to support the 'Sanctuary Sessions.' Keep up the hearts. 
What singing the 'Kings Shilling' means for today.

I got this song from Frank Harte, the great song collector and Irish singer, a man who was very good to me. I met him up in the Catskills in 1995 and he took me under his wing and said "come here to me young one, I need to teach you a few decent songs." And so he did. He changed the course of my life really setting me off on a pathway of these lovely songs. Irish song continues to be the real narrative of our country. We tell all our stories through these songs, often giving voice to the powerless and underprivileged and singing out against oppression. That is our gift to the world. We are very good with the old words.

The King's Shilling was written by Iain Sinclair and it calls for an end to violence. It speaks again to that time honoured Irish and Scottish tradition of defiance of speaking out against colonialism. A long line of thought that has never been broken. Colonialism has failed us all. It fails us today in Yemen, Ethiopia, Sudan and Somalia with famine raging. In Syria, with hundreds of thousands of refugees fleeing. We have to look after these people. Justin Trudeau has just taken in 30,000 refugees. We can do that too. As an Irish woman the cultural memories that these events evoke are horrifying.

For myself while we can talk about these bigger issues I see colonialism in all its guises. A powerful group making 'other' people feel small. A band of men coercing a woman. Making anyone feel small, fails us all. We have to lean into our shared sense of humanity now more than ever.

I came to NY as an immigrant in 1993, I worked in the restaurants downtown where I worked with my Mexican brothers and sisters to put exotic food on the tables. I worked as a nanny where I minded a lovely little boy called Ted and went to the park every day and sat out with my sisters from the Caribbean in the beautiful sunshine of the East river. Tonight I am singing in Carnegie Hall. Immigrants are what make America good. And I love what is good about America, opening arms to the poor and underprivileged. Giving hope to the world. We are all immigrants here on the stage. So I stand in solidarity with all of the immigrants. There is no need to be banning Muslims or building walls, making people feel afraid. The only thing we need to build now are the pillars of social justice based on love and peace.

So I stand in this legacy of the Irish folk singer. I have been standing here for twenty-five years, giving out really, sometimes very alone as a woman in a deeply misogynistic world we call the music industry, asking continually for a better world. I have fought long and hard to get here. So a better world is one which brings an end to poverty, brings absolute equality for women in all aspects of our lives and which brings an end to war mostly caused by greed. A nation is judged by its vulnerable and poor and how they are treated.

Jim Larkin a great English man asked the Irish nation to get up off its knees. I am asking the same. We need to get up off our knees, fight the good cause and get out there and get active. Billy Bragg who recently spoke at the Folk Alliance asked that we put our empathy to action.

Join the 'Sanctuary Sessions' on the 5th March to raise money for the ACLU.

Every generation has to fight for its freedoms. I have had to fight for my own. I intend to keep fighting the only way I know and that is by singing. So I ask you respectfully to join me in singing out for our shared humanity. If ye need a song for Sunday this is a good one! If you are somewhere else in the world you can still show solidarity and sing or play somewhere. Please place your trust in one another and come together in peace and love.

"Pray for the dead and fight like hell for the living."

Mother Jones.

I then went on to write this new song about the present administration in America. In arguing that my performance is a performance for social justice, I feel that there is inherent intellectual knowledge continually being sought in each performance. In my case, I am arguing that my performative knowledge is constantly 'topped-up' or enlightened with each and every engagement in my practice and new insights and experiential knowledge are continually sought and give meaning to the songs in the moment of the performances. Therefore, I built on my performances and 'speeches' and wrote this song. This is just a 'rough take.' 
Who's going to build your wall? Not me.

https://soundcloud.com/karan-casey/whos-going-to-build-your-wall-not-me

\section{Feminism}

My ideas on feminism are expressed in singing The Kings' Shilling and performatively imagining the plight of the poor woman. I am identifying with this woman by singing out her voice, her woes, and her reality in the song and in that expression, giving her life experience credence and value.

On a more intimate, subconscious and a more obvious level, my own truth is expressed as a woman. I have to ask is a woman singing, in itself, a symbol of empowerment or a political statement? When a woman takes to the stage, she has to own that stage. She has to be very confident in herself and in her ability to share her emotions and to hand over her delivery of the song to the audience. Woman singers, unlike woman instrumentalists, have strong role models in our society. Growing up in Ireland, I went to concerts by Maura O' Connell, Mary Black, and Mary Coughlan and witnessed their great presence on the stage. It was an amazing gift again for me to receive this unspoken wisdom and power that can be passed on gesturally and emotionally through the experience of a performance. I was learning even then, even though it didn't feel like it.

As a woman do I perform my gender? Judith Butler (1988) theorises gender as performative. She based her work in Gender trouble: Feminism and the subversion of identity (1990) among other people on the writings of Simone de Beauvoir and Michel Foucault. In an earlier essay, 'Performative acts and gender constitution' (1988), Butler compares Maurice Merleau-Ponty the phenomenologist's work with the feminist Simone de Beauvoir arguing that both theories were grounded in 'lived experience'. Butler argued that both theories see gender as a historical idea or situation; stating that "When Beauvoir claims that 'woman' is a historical idea and not a natural fact, she clearly underscores the distinction between sex, as biological facticity, and gender, as the cultural interpretation or signification of that facticity" (Butler, 1988, p. 522). This was the groundwork for her view that gender was "theatrical" or performative in the world, suggesting a social audience. If we accept her idea that the body is a historical idea and that gender then becomes natural or innate because the body "becomes its gender through a series of acts which are renewed, revised, and consolidated through time," (Butler, 1988, p. 523), then we can undo the myth that gender is innate and thus learned and performed.

To superimpose Butler's theory of performative gender onto my Irish identity, do I perform my Irish identity and more so when I am in America or abroad? Is my Irish identity free and flexible? Surely that is performed as well? Am I acting out or performing my gender, also when I sing older songs that venerate Irish male heroes and where is the place for women here? I have long argued that I inhabit the voice of the powerless, both male and female, and in doing so I sing out against oppression. I also recognise the power of the imagination at play here. Honouring the heroes of the past who have fought against British colonialism has been for me a way of speaking out against colonialism today. I see this as the long and time-honoured tradition that many traditional and folksingers employ. But where does it leave me as a woman? Am I furthering the myth that men need to go to war for the honour and glory of Ireland and that the woman's issues or feminism can wait? Am I continually writing women out of history by singing these songs? Or is the opposite true? How does the fact of my being a woman affect the audience? Are they more receptive to my political opinion because it sounds 'nice' or does it wash over them because it sounds 'nice.'

Is this female current of identity so strong that when I perform do I performatively 'get away with more' when I sing the political songs of old from Ireland? Am I the embodiment of oppression and therefore not seen as such a threat to the status quo when I sing revolutionary songs or songs that have a potent political bent? I don't believe that I am the embodiment of oppression and I certainly do not feel this way when I am 
on the stage, but I often wonder how seriously my opinion is taken. My heart is always trembling.

\section{Discussion and Conclusion}

The tricky part of conducting social justice through songs that I constantly grapple with is my own sense of fair-mindedness towards the audience's night out. People are out to enjoy themselves I sometimes have to remind myself. I don't know if this will ever be truly resolved within me. What I do is go to other people's gigs and see how they approach this. I try to learn from other performers, and now as a researcher, I try to reflect more on these issues. I also balance the performance with other types of song, even though I stress and again agree with Dick Gaughan that all of the songs I sing are a kind of love song for humanity.

Songs that provide a balance to the social justice issues or perhaps give a wider emotional spectrum include: Lovely Annie, a song I wrote for my mother; All the Things I Do, another self-composed songs on the issue of love; Hold On for compassion; Jimmy Crowley and Pat Daly's traditional song The Doll in Cash's Window; and Ger Wolfe's Curra Road for joy. This mixture of song themes is a reflection of the panorama of life, the politics being one aspect of my life. Of course all of the songs are for my deep love and the sheer joy of music. Again this involves allowing and handing over the authority to the audience and you the viewer to decide for yourself how to judge the songs. This is really a little vignette into the machinations of my head.

\section{"And so to conclude and to finish my rhyme \\ I hope you'll excuse me for wasting your time"}

So to conclude, my main concern for the concert and my performance in terms of social justice is am I speaking to the converted or do I alienate people who feel as if they are being preached to? I have spent years caught between these two questions. In the beginning, I innocently thought that getting out there and singing songs for and from the point of view of the voiceless and under-represented would change the world. I thought if people knew or could 'feel' how bad things were then they would change. How naïve a young woman can be. When I sing for social change, now I am envisioning a world without poverty, where women are treated as equals and where there is an end to colonial wars and strife, or in other words an end to greed. I do believe that the words and performance promote compassion and are powerful forces of evocation and illumination into the human condition of love. I believe that performatively and textually the songs do contribute to a discussion on social justice.

The performance space that I have been afforded through my singing is a really sacred area for me. It mirrors the smallest, quietest part of myself that is often very vulnerable and afraid. It allows me to grow tall; it allows me on the good days to explore these issues that are so important to me as a person and as a singer. It allows me to be become the woman I want to be. These notions might seem too high and mighty or too lofty a world to live by, but they have sustained me so far. This is a far reaching creative worldview and indeed it has been the philosophical underpinning of all of my inquiries into singing. Sing out!

\section{Acknowledgements}

Thank you to Dr. Sandra Joyce, Professor Mick Moloney, and Dr. Michael Viega. 


\section{Notes}

1. Frank Harte (1933- 2005) Traditional Irish singer, song collector, architect, and lecturer. Frank had a profound influence on me and many other Irish singers: namely Mick Moloney, Mary Black, Paul Brady, Christy Moore, Andy Irvine, Len Graham, Niamh Parsons, and countless others for his tremendous generosity in the transmission of Irish traditional song. He produced 10 albums of traditional song which are an invaluable resource not just for the songs but for the historical and social information in the booklets.

\section{References}

Bartleet, B. (2009). Behind the baton: Exploring auto-ethnographic writing in a musical context. Journal of Contemporary Ethnography, 38(6), 713-733, https://doi.org/10.1177/ 0891241609341638.

Breathnach, B. (1971). Folk music and dances of Ireland. Cork: Mercier Press.

Butler, J. (1988). Performative acts and gender constitution: An essay in phenomenology and feminist theory. Theatre Journal, 40(4), 519-531, https://doi.org/10.2307/3207893.

Chang, H. (2008). Auto-ethnography as method. Walnut Creek, CA: Left Coast Press.

Ellis, C., Adams, T., \& Bochner, A. (2010). Autoethnography: An overview. Forum Qualitative Sozialforschung / Forum: Qualitative Social Research, 12(1), 10.

Eyerman, R., \& Barretta, S. (1996). From the 30s to the 60s: The folk music revival in the United States. Theory and Society, 25(4), 501-543, https://doi.org/10.1007/BF00160675.

Harte, F. (1998). The first year of liberty. Dublin: Hummingbird.

Inequality.org. (n.d.) Facts: Global inequality. Retrieved from: https://inequality.org/facts/ global-inequality/

O Canainn, T. (1978). Traditional music in Ireland. Cork: Ossian. 